\title{
Storage fungi and mycotoxins associated with stored smoked Catfish (Clarias gariepinus)
}

\author{
${ }^{1}$ OSIBONA, AO; ${ }^{1}$ OGUNYEBI, OO;*2SAMUEL, TO
}

Department of Marine Sciences, Faculty of Science, University of Lagos, Department of Botany, Faculty of Science, University of Lagos *Corresponding author: temmitade@yahoo.com, tosamuel@unilag.edu.ng, Tel: +2348036410449

\begin{abstract}
Studies were carried out to determine the occurrence of storage fungi and their respective mycotoxin in stored smoked dried fishes. A total of 45 fishes were bought fresh, smoked and stored under three different storage conditions (an air tight container, a bamboo basket and an iron basket). Using the pour plate method, isolation and identification of storage fungi were carried out weekly for four consecutive weeks from each storage container. Mycotoxin detection and quantification were also carried out on each stored smoked fish samples using Agra-Quant kit. The proximate analysis of the stored fish samples prior to storage, and after storage from each storage container was also analysed. Results revealed five fungal isolates associated with the stored samples namely: Aspergillus flavus, A. fumigatus, A. niger, A. wentii and Penicillium species. Four species of Aspergillus and one Penicillium species were isolated and identified from two of three storage condition used (bamboo basket and iron basket) from third week of storage. It was deduced from the mycotoxins analysis results that Aflatoxin B1 and Ochratoxin were present in the stored smoked samples of the two above mentioned storage containers. Results from the proximate compositions revealed a decrease in the ash content, crude fiber and crude protein as the storage period increases. Fat and moisture content of the stored fish samples were observed to increases weekly throughout the storage period in bamboo basket and an iron basket. In conclusion, it can be deduced that storage container play a vital role in the preservation/shelf -life of smoked dried fish.
\end{abstract}

\section{DOI: https://dx.doi.org/10.4314/jasem.v22i5.6}

Copyright: Copyright $\odot 2018$ Osibona et al. This is an open access article distributed under the Creative Commons Attribution License (CCL), which permits unrestricted use, distribution, and reproduction in any medium, provided the original work is properly cited.

Dates: Received: 02 March 2018; Revised: 09 April: 2018; Accepted: 20 April 2018

Keywords: Storage fungi, Mycotoxin, smoked dried fish, proximate analysis.

Fish is an extremely perishable food. Spoilage proceeds as a series of complex enzymatic, microbial and chemical changes that begin as soon as the fish dies (Junaid et al., 2010). Fish processing and preservation is carried out mainly to slow down or prevent the enzymatic, microbial and chemical deterioration of fresh fish. In Nigeria, fish is eaten fresh, preserved or processed. The percentage composition of the different methods of fish disposed for consumption in the artisanal sector according to Tobor, (1984), are as follows live fish $7 \%$, fresh fish $27 \%$, smoke dried $45 \%$, sun dried $20 \%$ salted and sun dried $10 \%$. A number of processing techniques are in operation in Nigeria. These include chilling, freezing, salting, canning, drying and smoking. However, fish smoking is the most practiced preservation method in Nigeria. Smoke drying methods used in Nigeria requires low capital, investment and it is conducted in fishermen camps and fish processing centers in traditional smoking kilns of clay, cement blocks, drums or iron sheets (Eyo, 1992).

From the processing units to market centers, smoked dried fish are often contaminated with microorganisms such as bacteria, yeasts and moulds (Okafor and
Nzeako 1985, D’Andrea, 2012). Nigeria's high temperature, lack of processing and storage facilities can be responsible for the susceptibility of fish to damage and spoilage. Numerous pathogenic agents isolated from different types of fish are able to grow and produce their toxic secondary metabolites, which are retained in fish flesh even after salting and storage periods. These toxic substances caused serious systemic dysfunctions and public health hazards (Swaminathan and Sparling, 1998).

This study therefore aims at investigating storage fungi and mycotoxins associated with stored smoked Catfish (Clarias gariepinus).

\section{MATERIALS AND METHODS}

Sample source: Fish samples African Cat fish, (Clarias gariepinus) used for the project were purchased from Lagos state fish farm Estate Ikorodu, Lagos state. A total of 45 fresh fishes with an average weight of $400 \mathrm{~g}$ were bought.

Sample preparation: The collected fish samples were washed cleaned smoked for $48 \mathrm{~h}$ under monitored ambient conditions. The dried fish samples were 
divided into three groups. A set fifteen fish samples were placed in a tightly covered storage bowl (label A), another set in a covered bamboo basket (label B), while the third set of fish samples were an iron basket (label C). These three storage container are stored at room temperature in the aquaculture unit of the Department of Marine Science, University of Lagos. Lagos.

Medium preparation: Twenty grammes of commercially produced Potato dextrose agar (PDA) was dissolved in five hundred millilitres $(500 \mathrm{ml})$ of distilled water and they were allowed to homogenize in a water bath. The medium were later sterilized by autoclaving in an autoclave at $121^{0} \mathrm{C}$ for 15 minutes. Chloramphenicol was added to the medium (the antibiotic is to inhibit the growth of any bacterial species that could contaminate the isolate), before pouring the melted medium into a sterile Petri plates (15-cm diameter Petri plates at a depth of $4.0 \mathrm{~mm}$ ), and cool at room temperature to solidify.

Isolation and identification of storage fungi: A little portion of the stored sample feed was collected from each of the storage container at the interval of seven days for six consecutive weeks. Using the direct inoculation method by Watanabe (2002), each of these collected feed was inoculated on the prepared PDA medium plate and incubated at $26^{\circ} \mathrm{C}$. Developed colonies of fungi were sub-cultured to obtain pure cultures. The fungi cultures were examined both macroscopically and microscopically for colony, mycelia and spore characteristics. The characteristics were compared with those in a standard mycology text (Vashishta and Sinha, 2005).

Proximate Composition of the Stored Feed: Proximate composition of the stored fish samples randomly picked from each storage container prior to and after storage period was carried out. This was analysed according to the method of A.O.A.C. (2005). This includes determination of ash content, crude fibre, crude protein, crude fat, nitrogen free extract and moisture content.

Mycotoxin detection and quantification: Assay Principles: The Agra Quant Aflatoxin is a direct competitive enzyme linked immunosorbent assay ELISA in a microwell format which allows the user to obtain exact concentrations in part per billion (ppb). Free aflatoxin in the samples and controls are allowed to compete with enzyme-labelled aflatoxin B1 (conjugate) for the antibody binding sites. After a wash step, substrate is added, which reacts with the bound conjugate to produce blue colour. More blue colour means less aflatoxin B1. The test is read in a microwell reader to yield optical densities of the controls from the standard curve, and the sample optical densities are plotted against the curve to calculate the exact concentration of aflatoxin B1.

Statistical Analysis: Descriptive statistics for all parameters were calculated in triplicate for smoked dried fish samples and six weeks old stored feed sample in the three storage containers. All these were reported as means \pm standard deviation.

\section{RESULTS AND DISCUSSION}

In the first two weeks of storage, no mould (fluffy patches) was sighted in the three storage containers. At the end of the third week of storage; blue green fluffy patches (mould/fungi) were noted on fish samples in container labelled B and C. In the subsequent weeks of storage (fourth and fifth), more fluffy patches of different colouration were noted on fish samples in the storage container labelled and C. Storage container A showed no mould/fungi growth throughout the storage period. Five fungi species were isolated and identified. These are Aspergillus flavus, A. fumigatus, A. niger, A. wentii and Penicillium species.

By extrapolation from the standard curve, concentration value of aflatoxin B1 in stored fish samples in storage container labelled A, B and C after storage period was given using the formula $\mathrm{y}=\mathrm{mx}+$ c. Where $y$ is the mean peak area, $x$ is the slope and $c$ is the intercept. Therefore, $\mathrm{x}=\mathrm{y}-\mathrm{c} / \mathrm{m}$. Fish samples in storage container $\mathrm{C}$ had the highest concentration of aflatoxin B1 with $1.5 \mathrm{ug} / \mathrm{ml}$, this is followed by fish samples in storage container B with $1.0 \mathrm{ug} / \mathrm{ml}$. The storage container A samples showed zero $u g / m l$ for the presence of aflatoxin B1. For ochratoxin, extrapolation standard curve using same above formula $(y=m x+c)$ reviewed that its concentration is zero $u g / m l$ in stored fish samples in storage container A while its $0.4 \mathrm{ug} / \mathrm{ml}$ and $0.8 \mathrm{ug} / \mathrm{ml}$ were recorded in stored fish samples in container B and C respectively.

From the proximate analysis, it was showed that at the end of the storage period, there was decrease in the protein, ash and the crude fibre content of the stored fishes. Though, there is little or no significant different in the decreases observed in fishes stored in container A, while ash content percentage decreased from 17.24 to 13.65 and 13.00 in storage container labelled B and $\mathrm{C}$ respectively. The protein content percentage also decreased from 50.38 to 45.02 and 44.27 in storage container labelled $\mathrm{B}$ and $\mathrm{C}$ respectively. Reduction was also noted in the percentage of the crude fibre content of the stored fishes. It reduced from 7.85 to 
4.00 and 3.00 in the storage container labelled B and $\mathrm{C}$ respectively (Table 1 ). In contrast to the decreases noted in the protein, ash and the crude fibre contents of the stored fishes, there was increase in the moisture and crude fat content of the fishes. The moisture content percentage increased from 8.20 to 17.84 and
18.50 in the storage container B and C respectively. The same trend was observed in the crude fat content of the stored fishes. Prior to storage, the crude fat was 24.36 percent. This was increased to 27.76 and 29.00 percent in the fish samples stored in the container labelled B and C (Table 1).

\begin{tabular}{|c|c|c|c|c|}
\hline $\begin{array}{l}\text { Proximate } \\
\text { component }\end{array}$ & $\begin{array}{l}\text { Freshly } \\
\text { prepared fish } \\
\text { samples }(\%)\end{array}$ & $\begin{array}{l}\text { Fish samples in } \\
\text { container labelled } \\
\text { A }(\%)\end{array}$ & $\begin{array}{l}\text { Fish samples in } \\
\text { container labelled } \\
\text { B }(\%)\end{array}$ & $\begin{array}{l}\text { Fish samples in } \\
\text { container } \\
\text { labelled } \mathrm{C}(\%)\end{array}$ \\
\hline Crude fibres & 7.85 & 7.65 & 4.00 & 3.00 \\
\hline Ash content & 17.24 & 17.28 & 13.65 & 13.00 \\
\hline Crude protein & 50.38 & 50.35 & 45.02 & 44.27 \\
\hline Crude fat content & 24.36 & 24.42 & 27.76 & 29.00 \\
\hline Moisture content & 8.20 & 8.40 & 17.85 & 18.50 \\
\hline
\end{tabular}

The results from this study reveals that there was no of fungal growth was observed in container A which was air tight throughout the storage period. This may be due to the fact that storage container A prevents external environmental factors from interfering with the stored fish samples. This is in agreement with the requirements for suitable packaging for dried fish which include inertness, leak proof, impermeability to oxygen and moisture, low transparency and resistance to abrasion and puncture (Gopal and Shankar, 2011). Also, in agreement with Samuel and Odunigba, (2016), where it was reported that no fungal growth was observed in stored sample feed in a tightly covered storage bowl.

According to Pitt and Hocking, (2009), Adebayo-Tayo et al., (2008), Essien et al. (2005), and Fafioye et al., (2008) in support of the findings on the isolated storage fungi associated with stored smoked fishes, Aspergillus species are recognized as dominant fungi species. The decrease observed in proximate analysis result on crude fibre, protein and ash content according to Jallow (2010), is related to different storage methods employed in the study. The increase recorded in the moisture content of stored fishes in containers B and $C$ is in supported of the findings of Daramola et al (2007), in which it was reported that increase in moisture is due to relative humidity differences in the storage containers used in this study.

Detection of Aflatoxin and Ochratoxin A in the stored fish samples as a result of presence of species of Aspegillus and penicillium as those stored fish samples in storage container A without any trace of fungi species show no Aflatoxin and Ochratoxin A. Urbano et al. (2001) and FAO (2008), reported that the level of aflatoxin in human body must not be more than $20 \mathrm{ppb} / 6 \mu \mathrm{g} / \mathrm{kg}$ while the Scientific Committee on Food of the European Union proposed that the maximum daily intake of Ochratoxin should not exceed $5 \mu \mathrm{g} / \mathrm{kg}$ (WHO 2006).

From this study, it can be deduced that of the three storage containers used, storage container A which was air tight is the best storage container for smoked fish products which is in agreement with Gopal and Shankar (2011), that requirements for suitable storage/package of smoked fish include inertness, leak proof, impermeability to oxygen and moisture, low transparency and resistance to abrasion and puncture.

Conclusion: It was gathered from the results in this present study that, to prevent mycotoxin contamination in stored smoked fish products, proper storage and package devices should be employed. This is becomes necessary as the consumption of mycotoxins which is undegradeable can lead to serious health hazard to humans who is the final consumer of the stored smoked fish products. There should be more awareness on the danger associated with the consumption mycotoxins contaminated fish products to the general public.

Acknowledgment: The authors thank Aquaculture unit, Department of Marine Sciences, Faculty of Science, University of Lagos for accessing their facilities.

\section{REFERENCES}

Adebayo-Tayo, BC; Onilude, AA; Patrick, UG (2008). Mycoflora of smoked dried fishes sold in Uyo, Eastern Nigeria. WJAS 4: 346-350.

AOAC. (2005). Official Methods of Analysis. 18th Edn., Association of Official Analytical Chemists, Washington, DC., USA.

D'Andrea, C (2012). Guidelines on Assessment and Remediation of Fungi in indoor Environments 
New-York city Dept. of Health and Mental Hygiene. New York, USA.

Daramola, JA; Fasakin, EA; Adeparusi, EO (2007). Changes in physicochemical and sensory characteristics of smoke-dried fish species stored at ambient temperature. African journal Food Agric. Nutr. Dev., Vol. 7.

Essien, JP; Ekpo, MA; Brooks, AA (2005). Mycotoxin and proteolytic potential of moulds associated with smoked shark fish (Clamydoselacus anguinesis) Jour .of Applied Sci. and Env. Mgt. 9, $53-57$.

Eyo, AA (2012). Traditional and improved fish handling, preservation and processing Techniques. NAERLS/NIFER national workshop on fish process storage, marketing and utilization, $15-20 \mathrm{pp}$.

Fafioye, OO; Fagbohun, TR; Olubanjo, OO (2008). Fungal infestation and nutrient quality of traditionally smoked dried fresh water fish. Turk J Fish Aquat Sci, 8: 7-13.

FAO. (2008). Fisheries and Aquaculture Report. No. 889. Food and Agriculture Organization of the United Nations (FAO), Cairo, pp: 61.

Gopal, TKS; Shankar, CNR (2011). Quality and safety of packaging materials for aquatic products: Hand book of sea food quality, safety and health applications. West Sussex: Blackwell publishing Ltd.

Jallow, AM (2010). Contribution of Improved chorkor oven to artisanal fish smoking in the Gambia. Workshop on seeking improvement in Fish Technology in West Africa. IDAF Technical Report, No. 66.
Junaid, SA; Olauboin, F; Olabode, AO (2010): Mycotic contamination of stock fish sold in Jos, Nigeria. J. Yeast Fungal Res 1(7): 136 - 141.

Okafor, N. and Nzeako, B.C. (1985). Microbial flora of fresh and smoked fish from Nigerian Fresh Water. F. Microbiol., 2: 71-75.

Pitt, JI; Hocking, AD (2009). Fungi and food spoilage (Thirded.) New York; Springer Science + Business Media.

Samuel, TO; Odunigba, O (2015). Aflatoxins associated with storage fungi in fish feed. Ife Journal of Science. . 17 (2): 517-521

Swaminathan, B; Sparling, PH (1998). The bacteriology of food excluding dairy products. In: Toply and Wilson. Collier L, Balows A, Sussman M. Microbiology and microbial infection. (9th Edn.), Vol. 2 Edward Arnold Publishers Ltd, 407408pp.

Tobor, JG (1984). A review of the fishing industry in Nigeria and status of fish preservation methods and future growth prerequisites to cope with anticipated increase in production NIOMR Tech pap. Nigerian food Journal, 2: 105-108.

Urbano, GR; Taniwaki, MH; Leiatao, MF; Vicentini, MC (2001). Occurrence of ochratoxin A producing fungi in raw Brazilian coffee. Journal of Food Protection 64: 1226-1230.

Vashishta, BR; Sinha, AK (2005). Botany for degree students fungi. S. Chand and Company Ltd, New Delhi. 676pp.

Watanabe, T (2002). Pictorial Atlas of Soil and Seed Fungi. Morphologies of Cultured Fungi and Key to Species. $2^{\text {nd }}$ Ed. CRC Press, Boca Raton. 506pp

World Health Organization. (2006). Mycotoxins in African foods: Implications to food safety and health (AFRO Food safety (FOS). 